\title{
Leaf tissues proportion and chemical composition of Axonopus jesuiticus $x$ A. scoparius as a function of pig slurry application
}

\author{
Proporção de tecidos foliares e composição química de Axonopus jesuiticus x A. scoparius em \\ função da aplicação de dejeto líquido de suíno
}

\author{
Cristiano Reschke Lajús ${ }^{I}$ Mário Miranda ${ }^{I I}$ Simone Meredith Scheffer-Basso ${ }^{\text {III }}$ \\ Cercí Maria Carneiro $^{\mathrm{IV}}$ Pedro Alexandre Varella Escosteguy ${ }^{\mathrm{II}}$
}

\begin{abstract}
This study aimed to evaluate the chemical and anatomical attributes of leaves of giant missionary grass to application of $0,62,124,186,248$ and $310 \mathrm{~m}^{3} \mathrm{ha}^{-1}$ of pig slurry. At 83 days after the last application of fertilizer, the leaf blades were collected, fixed in FAA 70\%, sectioned, stained, photographed and digitalized. The transversal section of leaf blades were evaluated for proportion of epidermis, lignified vascular tissue + sclerenchyma, non-lignified vascular tissue and parenchyma with an image-processing system calibrated to $1 \mathrm{~mm}$ pixel ${ }^{-1}$. Leaf samples were analyzed for crude protein, acid detergent fiber, neutral detergent fiber and hemicellulose content by near infrared reflectance spectroscopy. The pig slurry application up to $310 \mathrm{~m}^{3} \mathrm{ha}^{-1}$ significantly increased the percentage of crude protein, parenchyma, epidermis, non-lignified vascular tissue and hemicellulose, while decreasing the percentage of acid detergent fiber and lignified vascular tissue + sclerenchyma. The Pearson's correlation was positive between crude protein and non-lignified vascular tissue, and between acid detergent fiber and lignified vascular tissue + sclerenchyma. The percentage of hemicellulose was positively correlated with epidermis, parenchyma and nonlignified vascular tissue. A negative correlation between acid detergent fiber and epidermis, parenchyma and non-lignified vascular tissue was observed.
\end{abstract}

Key words: crude protein, epidermis, fiber, lignified vascular tissue + sclerenchyma, parenchyma.

\section{RESUMO}

Este trabalho teve como objetivo avaliar os atributos anatômicos e químicos da grama-missioneira-gigante à aplicação de 0, 62, 124, 186, 248 and $310 \mathrm{~m}^{3}$ ha $^{-1}$. Decorridos 83 dias do último corte e da aplicação do dejeto, as lâminas foliares foram coletadas, fixadas em FAA 70\%, seccionadas, coradas, fotografadas e digitalizadas. Secções transversais das lâminas foliares foram avaliadas quanto à proporção das áreas de epiderme, tecido vascular lignificado + esclerênquima, tecido vascular não lignificado e parênquima, na região entre a quilha e o segundo maior feixe vascular, com sistema de processamento de imagem calibrado para $1 \mathrm{~mm}$ pixel ${ }^{-1}$. Amostras de folhas foram coletadas e analisadas quanto ao teor de proteína bruta, fibra insolúvel em detergente ácido e fibra insolúvel em detergente neutro, pelo método de espectrometria de reflectância no infravermelho proximal. A aplicação de até $310 \mathrm{~m}^{3} \mathrm{ha}^{-1}$ do dejeto líquido de suíno aumentou os percentuais de proteína bruta, hemicelulose, parênquima e tecido vascular não lignificado, reduzindo os percentuais de fibra insolúvel em detergente ácido e tecido vascular lignificado + esclerênquima. A correlação de Pearson foi positiva entre o percentual de proteína bruta e tecido vascular não lignificado, e entre o percentual de fibra insolúvel em detergente ácido e tecido vascular lignificado + esclerênquima. $O$ percentual de hemicelulose mostrou correlação positiva com epiderme, parênquima e tecido vascular não lignificado. Houve correlação negativa entre o percentual de fibra insolúvel em detergente ácido e epiderme, parênquima e tecido vascular não lignificado. O dejeto líquido de suínos, utilizado como fonte de nitrogênio, promove melhoria em atributos químicos e anatômicos, que afetam o valor nutritivo da grama-missioneira-gigante.

Palavras-chave: epiderme, fibra, parênquima, proteína bruta, tecido vascular lignificado + esclerênquima.

\section{INTRODUCTION}

Pig slurry is applied on pastures and crop lands to supply nutrients mainly nitrogen $(\mathrm{N})$ to non-legumes plants. Several studies has reported the positive effect of pig slurry application on the

\footnotetext{
'Universidade Comunitária da Região de Chapecó (Unochapecó), Av. Senador Attílio Fontana, 591-E, 89809-000, Chapecó, SC, Brasil. E-mail: clajus@unochapeco.edu.br. Autor para correspondência.

IIEmpresa de Pesquisa Agropecuária e Extensão Rural de Santa Catarina (Epagri), Chapecó, SC, Brasil.

IIIPrograma de Pós-graduação em Agronomia, Universidade de Passo Fundo (UPF), Passo Fundo, RS, Brasil.

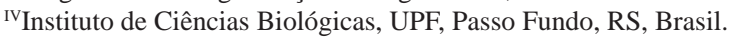


production and nutritive value of forage grasses (ADELI et al., 2005; SCHEFFER-BASSO et al., 2008; VIELMO et al., 2011). Besides of recognized effect of PS on increasing of forage production, the effects of this $\mathrm{N}$ source on anatomical feature are unknown, especially in native forage plants.

The accumulation of $\mathrm{N}$ in plants can change tissue proportions of leaves and chemical composition, affecting structural organization or anatomy of plant organs and its constituent tissues. This effect influences the intake, the nature of particles produced and their rumen passage rate, and cell wall digestibility, providing greater or smaller accessibility of its polysaccharides to rumen microorganisms (CARVALHO \& PIRES, 2008). In the same way, tissue proportions and cell wall thickness are important anatomical traits influencing nutritive value of grasses. The tissues lowest digested correlate negatively with $\mathrm{CP}$ and in vitro dry matter digestibility (IVDMD) (PACIULLO, 2002). In addition, neutral detergent insoluble fiber (NDF) and ADF has been correlated with leaf anatomy (QUEIROZ et al., 2000).

The giant missionary grass is native forage originated from Vale do Itajaí, Santa Catarina. It is a hybrid resulting from natural crossing between $\boldsymbol{A}$. jesuiticus Araújo (Valls) and A. scoparius (Flüggé) Kuhlm. It is also referred as A. catharinensis Valls, but the publication of this name is not yet formalized. It is a perennial and warmer grass, with high yield response to pig slurry fertilization (MIRANDA et al., 2012). The objective of this study was to evaluate the effect of pig slurry fertilization on chemical and anatomical attributes that affect the nutritional value of this hybrid.

\section{MATERIAL AND METHODS}

The evaluated leaves were sampled on an experiment were the giant missionary grass (accession V14337 - BRA-002020) was fertilized with pig slurry (PS) rates for two years (MIRANDA et al., 2012). This experiment was carried out in Epagri Experimental Station, in Chapecó, Santa Catarina. The climate is subtropical classified as Cfa and the soil is classified as dystrophic oxisol. A randomized complete block design, with five replications, and plots of $30 \mathrm{~m}^{2}(5 \mathrm{~m}$ x $6 \mathrm{~m}$ ) were used. The studied leaves were sampled in the first year of the experiment (2007/2008). Along this year the following rates of PS were applied: 0,62 , 124, 186, 248 and $310 \mathrm{~m}^{3} \mathrm{ha}^{-1}(0,100,200,300,400$ and $500 \mathrm{~kg} \mathrm{~N} \mathrm{ha}^{-1}$, respectively). To evaluate the tissue proportion and the chemical composition of the leaves, three samples of leaves were taken in each plot of the one block, in September $15^{\text {th }}$ of 2008. The sampling method is commonly used in anatomical studies, in which the samplers constitute the replications and the experimental design is considered as completely randomized (LIMA et al., 2001). Leaves were sampled when the plants were in vegetative stage and 83 days of regrowth. This time was assumed as appropriate because the growth season (spring) of the grass was beginning and the four fractions of the PS rates had been applied. Three green leaves per treatment were taken, being the second fully expanded leaf/tiller, from the top to bottom. The leaf blades were washed, sectioned in small pieces and fixed in formaldehyde: acetic acid: ethanol 70\% - 5:5:90 (FAA 70\%), for $48 \mathrm{~h}$, and stocked in alcohol 70\%. Transversal freehand sections were made at middle third of the blade, followed by staining with basic fuchsine diluted to $0.5 \%$ in ethanol $50 \%$ and Astra blue, to show the lignified walls and the cellulose walls in the leaf cells. The anatomical blades were photographed in light microscope Zeiss and the pictures were digitalized to measure the area of the tissues. The imageprocessing system Image Pro Plus 5.0 software, calibrated to $1 \mathrm{~mm}$ pixel $^{-1}$, was used to quantify the tissues according the cell wall nature (ALVES DE BRITO et al., 1999): a) epidermis, except trichomes and bulliform cells; b) lignified vascular tissue + sclerenchyma $(\mathrm{LVT}+\mathrm{S})$, including xylem, fiber, sclerenchymatic sheath and other cells with lignified wall cell that had present in vascular bundles; c) nonlignified vascular tissue (NLVT), including phloem and other cells in the bundles that presented cellulosic cell wall; d) parenchyma, including bulliform cells and bundle vascular parenchymatic sheath. The tissue areas of each replication were measured along the cross section from the keel until the second major vessel of the one side of the wing. To evaluate the chemical composition, three leaf samples were taken in the same plots used to obtain the leaf samples for anatomical study. The samples were dried at $60^{\circ} \mathrm{C}$ for $72 \mathrm{~h}$, weighted, ground before passing through a $1 \mathrm{~mm}$ screen and analyzed for percentage of CP, ADF, NDF and hemicellulose (HC) by near-infrared spectroscopy (NIRS), using the usual calibration method described by FONTANELI et al. (2004). The HC content was determined by difference between these two fractions (VAN SOEST et al., 1991). The dry matter (DM) content was determined by difference between the fresh and dried weight of the samples.

A regression analysis was established between the quantified tissues or the chemical analyses and the PS rates and a Pearson's linear correlation 
was established between these two kinds of variables (chemical composition and tissue proportion), using SISVAR software (FERREIRA, 2011). The dissimilarity between PS rates was checked by clustering analysis by using Ward's method, based in Mahalanobis distance $\left(\mathrm{D}^{2}\right)$. The relative importance of chemical and anatomical attributes affecting divergence among pig slurry rates applied on giant missionary grass was calculated according Singh's method (SINGH, 1981). The multivariate analysis was performed on Genes software (CRUZ, 1997).

\section{RESULTS AND DISCUSSION}

The proportion of epidermis and NVT linearly increased with increasing of PS application up to $310 \mathrm{~m}^{3} \mathrm{ha}^{-1}$, and a quadratic effect was observed for parenchyma tissue. A negative quadratic effect of fertilization was verified for $\mathrm{LVT}+\mathrm{S}$ (Figure 1). Although $\mathrm{N}$ availability is known to affect leaf elongation, its effect on leaf tissue proportion remains poorly understood, especially when the $\mathrm{N}$ source is manure. No references were found about the effect of PS fertilization on grass leaf anatomy, but the reduction of percentage of sclerenchyma and vascular tissue was reported for Panicum maximum Jacq. fertilized with mineral N (BASSO, 2009). Plant growing with lower available $\mathrm{N}$ tend to be woody and to have thick cell walls, presumably because much of the carbohydrate is deposited in these structures, whereas if availability of this $\mathrm{N}$ is higher it would be used in protein synthesis (SINNOT, 1960). Under N deficiency the excess of carbon assimilated are used for lignin formation and other cell wall components, increasing the concentration of cell wall and decreasing its digestibility (BELANGER \& McQUEEN, 1999). Thus, the leaf blade microanatomy and inherent characteristics of cell walls affect digestibility by rumen microorganisms (AKIN, 1989).

The effect of PS fertilization on leaf anatomy found on this study was positive since the tissue proportion improved as a result of this practice indicates higher nutritive value of the forage. The epidermis content increase is desirable because the inner wall of this tissue offers no resistance to microbial digestion, since the composition of its cell wall is equal to the mesophyll (CHESSON et al., 1986). In addition, the increase on the non-lignified vascular tissue and parenchyma proportion, which have high digestibility, and the reduction of the structural characteristics that limit forage breakdown, which are mainly the support tissue highly lignified, like sclerenchyma and xylem (AKIN, 1989), showed an improvement of the anatomical attributes that influences the nutritive value of the grass.

In a parental of giant missionary grass, Axonopus scoparius, the maturity of cultivars decreased the degradability of the forage, which was related to cell wall thickening and increased lignified tissue area (LIMA et al., 2001). Dynamics of lignification in cell walls can indicate the quality of forage plants, and many authors have linked the increase of tissue lignification as a result of maturity and management effects, as cutting and fertilization of grass, with a consequent decrease of the digestibility of forages to ruminants (ALVES DE BRITO et al., 1999). Since lignin concentration and the digestibility of the giant missionary grass were not evaluated in our study, such determinations must be included in future researches about PS fertilization effect on the nutritive characterization of this forage. However, our results can indicate a good trend about this effect.

The effect of PS rates did not affect chemical composition of NDF (average $=65 \%$ ). However, decreased of both ADF (-5.78\%) and DM contents (-26.6\%), and increased of CP (41.9\%) and HC contents (between 6.8 to 9.2\%) were observed (Figure 2). These results show that PS application would improve the digestibility of the giant missionary grass, since it is affected by these variables (AKIN, 1989). Determination of ADF, which consists of lignin associated with cellulose and other structural polysaccharides, has been suggested as the best chemical method for estimation of IVDMD (ROHWEDER et al., 1978). Forages with higher ADF are lower in digestible energy than forages with lower ADF, which means that ADF level increases, digestible energy levels decrease (SAHA et al., 2010). The highest CP percentage (12.2\%) was found at the highest rate $\left(310 \mathrm{~m}^{3} \mathrm{ha}^{-1}\right)$ of PS and was similar to also reported (11.0-14.7\%) for the giant missionary grass (DESCHAMPS \& TCACENCO, 2000). The same trend was reported for Cynodon spp. fertilized with pig slurry (SCHEFFER-BASSO et al., 2008; VIELMO et al., 2011). The effects found in this study are the same found with mineral $\mathrm{N}$ fertilization on grasses, which increases the water concentration, and at higher rates results in progressively greater concentrations of $\mathrm{N}$ in the plant tissue (BUXTON \& FALES, 1994). A quadratic effect of PS was observed in HC (Figure 2). ADELI et al. (2005) also verified a quadratic trend of ADF for bermudagrass (Cynodon spp.), with the highest content of these variables, 56.3 and $37.4 \%$, respectively, on the treatments with PS. VIELMO et al. (2011) observed decreased of 


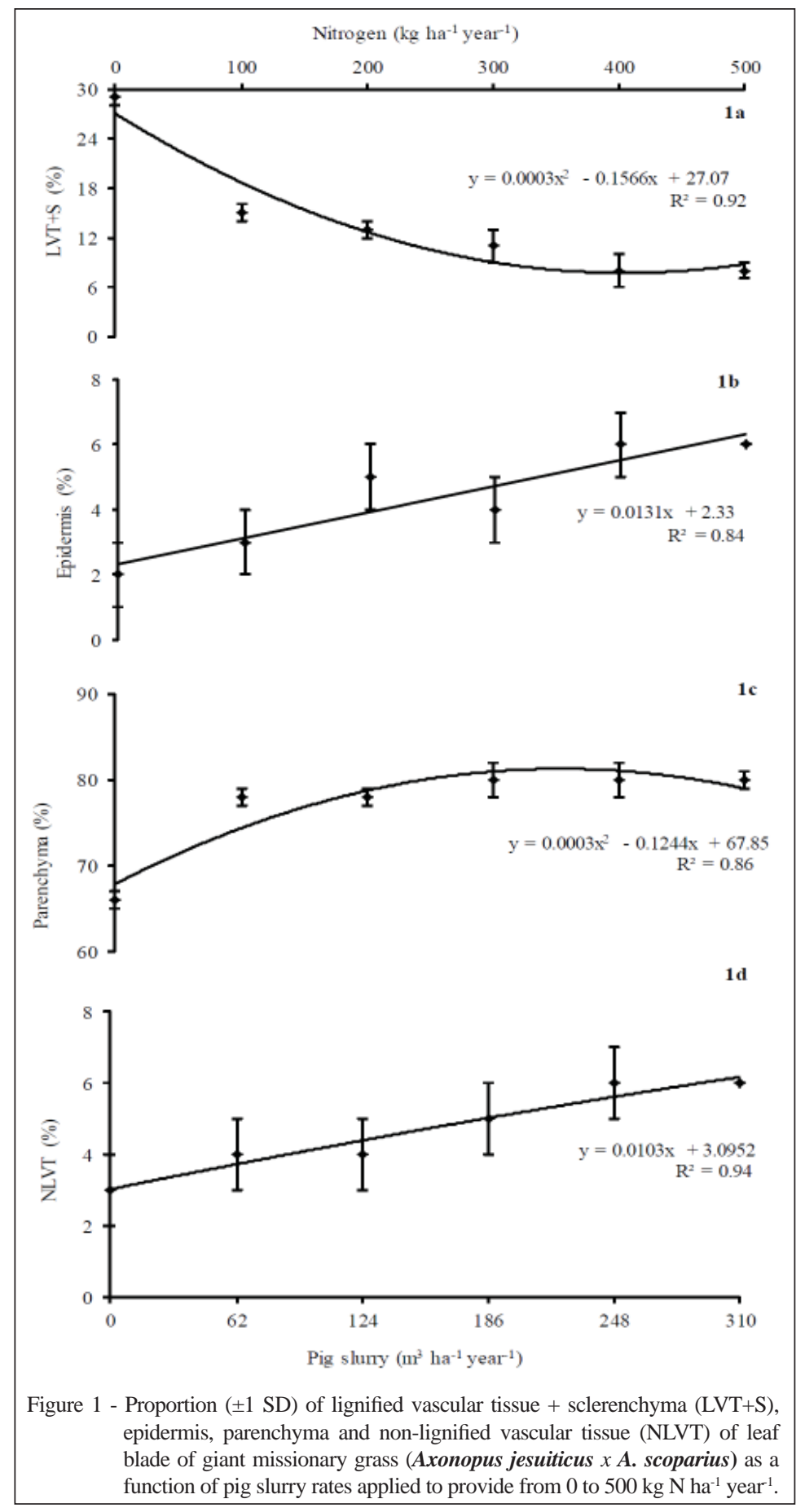

this fraction in Tifton 85 (C. dactylon (L.) Pers. $\mathbf{x}$ C. transvaalensis Burt Davy), and BARNABÉ et al. (2007) reported decrease in Brachiaria brizantha (Hochts. ex A. Rich) as a function of PS rates.

The Pearson's correlation between leaf tissue proportion and chemical composition showed positive association between $\mathrm{HC}$ and tissues with higher degradability (epidermis, parenchyma and NLVT), and negative correlation with LVT+S, a poor degradability tissue (Table 1). Opposite correlation was found between these tissues and the percentage of ADF. These results were similar to found for tropical grasses, where a positive correlation between epidermis and CP, and a negative correlation between 


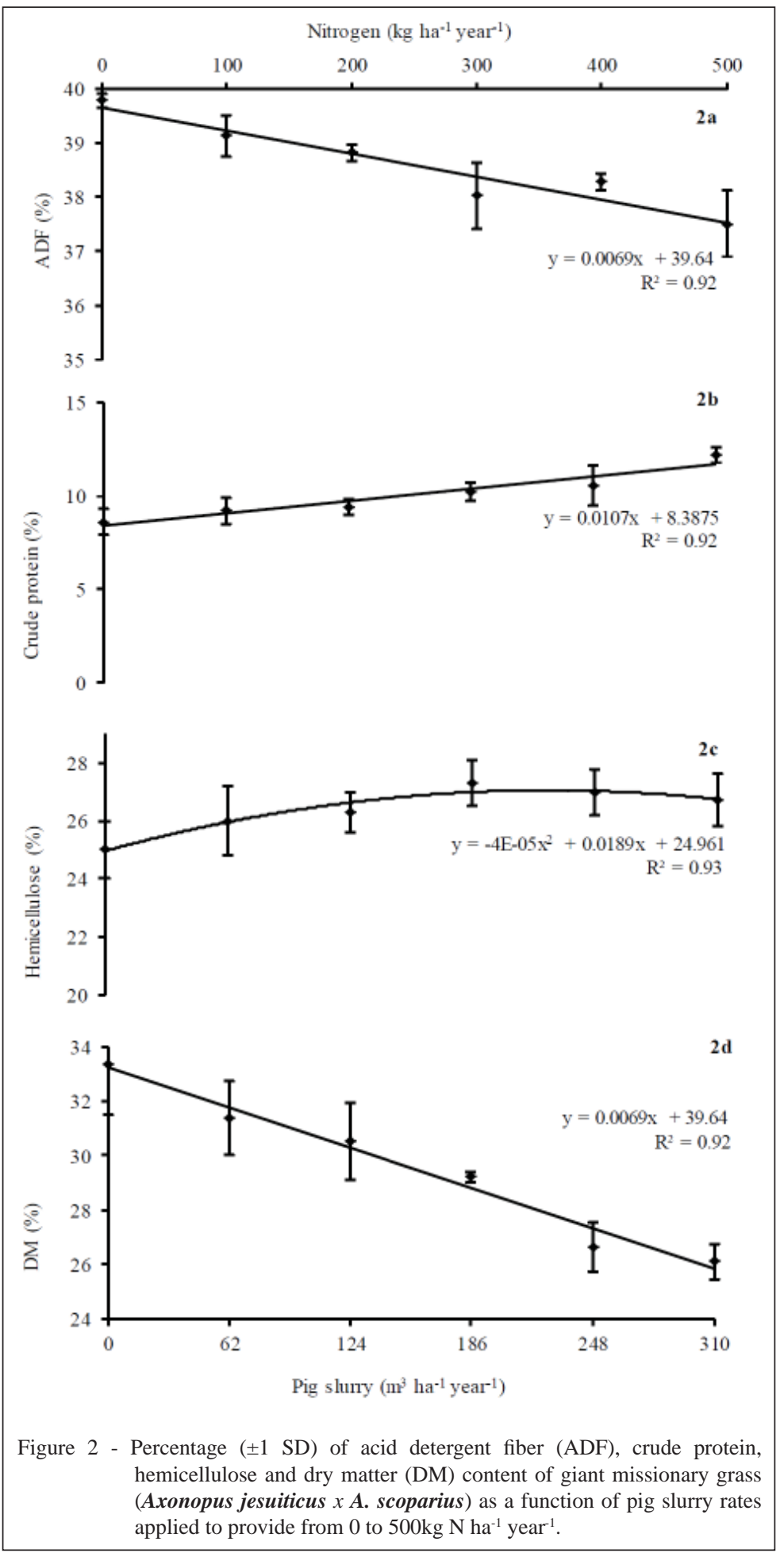

ADF and epidermis and ADF and lignified vascular tissue were observed (QUEIROZ et al., 2000).

The nutritive value of forage plants is the result of many attributes and therefore the effect of management practices can be better analyzed when it is considered the set of variables. The multivariate analysis showed that the attributed that exhibited greater relative contribution for divergence among the pig slurry rates were $\mathrm{LVT}+\mathrm{S}$, epidermis and parenchyma, which explained $96.9 \%$ of the variability 
Table 1 - Pearson's correlation coefficients between chemical composition and tissue proportions of leaf blade of giant missionary grass (Axonopus jesuiticus $x$ A. scoparius).

\begin{tabular}{|c|c|c|c|c|}
\hline \multirow{2}{*}{ Chemical composition } & & & & \\
\hline & Epidermis & Parenchyma & NLVT & $\mathrm{LVT}+\mathrm{S}$ \\
\hline CP (\%) & $0.77 \mathrm{~ns}$ & $0.62 \mathrm{~ns}$ & $0.91 *$ & $-0.73 \mathrm{~ns}$ \\
\hline $\mathrm{ADF}(\%)$ & $-0.82 *$ & $-0.81 *$ & $-0.91 *$ & $0.87 *$ \\
\hline Hemicellulose (\%) & $0.84^{*}$ & $0.83 *$ & $0.85 *$ & $-0.89 *$ \\
\hline DM (\%) & $-0.92 * *$ & $-0.79 \mathrm{~ns}$ & $-0.98 * *$ & $0.90 *$ \\
\hline
\end{tabular}

CP: crude protein. ADF: acid detergent fiber. DM: dry matter. LVT+S: lignified vascular tissue + sclerenchyma. NLVT: non-lignified vascular tissue. ${ }^{*} * *$ Significant by t test $(\mathrm{P}<0,05$ and $<0,01$, respectively). ns $=$ no significant $(\mathrm{P}>0,5)$.

among the pig slurry rates (Table 2). Three main groups were created in the dendrogram (Figure 3). The Group II (248 and $310 \mathrm{~m}^{3}$ ) was characterized by better indicators of nutritive value, by the lower proportion of $\mathrm{LVT}+\mathrm{S}$, and greatest proportion of parenchyma, epidermis and NLVT.

\section{CONCLUSION}

Pig slurry used as nitrogen source improves chemical and anatomical attributes that affect the nutritional value of the leaves of giant missionary grass.

Table 2 - Relative importance (R.I) of chemical and anatomical attributes affecting divergence among pig slurry rates applied on giant missionary grass (Axonopus jesuiticus x A. scoparius) and characterization of groups formed by Ward's method.

\begin{tabular}{llccc}
\hline Attribute & R.I (\%) & I $\left(0 \mathrm{~m}^{3}\right)$ & II $\left(244\right.$ and $\left.310 \mathrm{~m}^{3}\right)$ & III $\left(62,124{\left.\mathrm{and} 186 \mathrm{~m}^{3}\right)}\right.$ \\
& & 33.3 & 26.4 & 30.4 \\
DM & 0.4359 & 8.9 & 11.3 & 9.6 \\
CP & 0.3440 & 39.8 & 37.9 & 38.7 \\
ADF & 0.2954 & 25.1 & 27.0 & 26.5 \\
Hemicellulose & 0.2067 & 2.0 & 6.0 & 4.0 \\
Epidermis & 26.1434 & 29.0 & 8.0 & 43.0 \\
LVT+S & 50.7069 & 3.0 & 6.0 & 7.3 \\
NLVT & 1.7676 & 66.0 & 80.0 & 78.7 \\
Parenchyma & 20.1001 & & & \\
\hline
\end{tabular}

DM: dry matter. CP: crude protein. ADF: acid detergent fiber. HC: hemicellulose. LVT+S: lignified vascular tissue + sclerenchyma. NLVT: non-lignified vascular tissue.

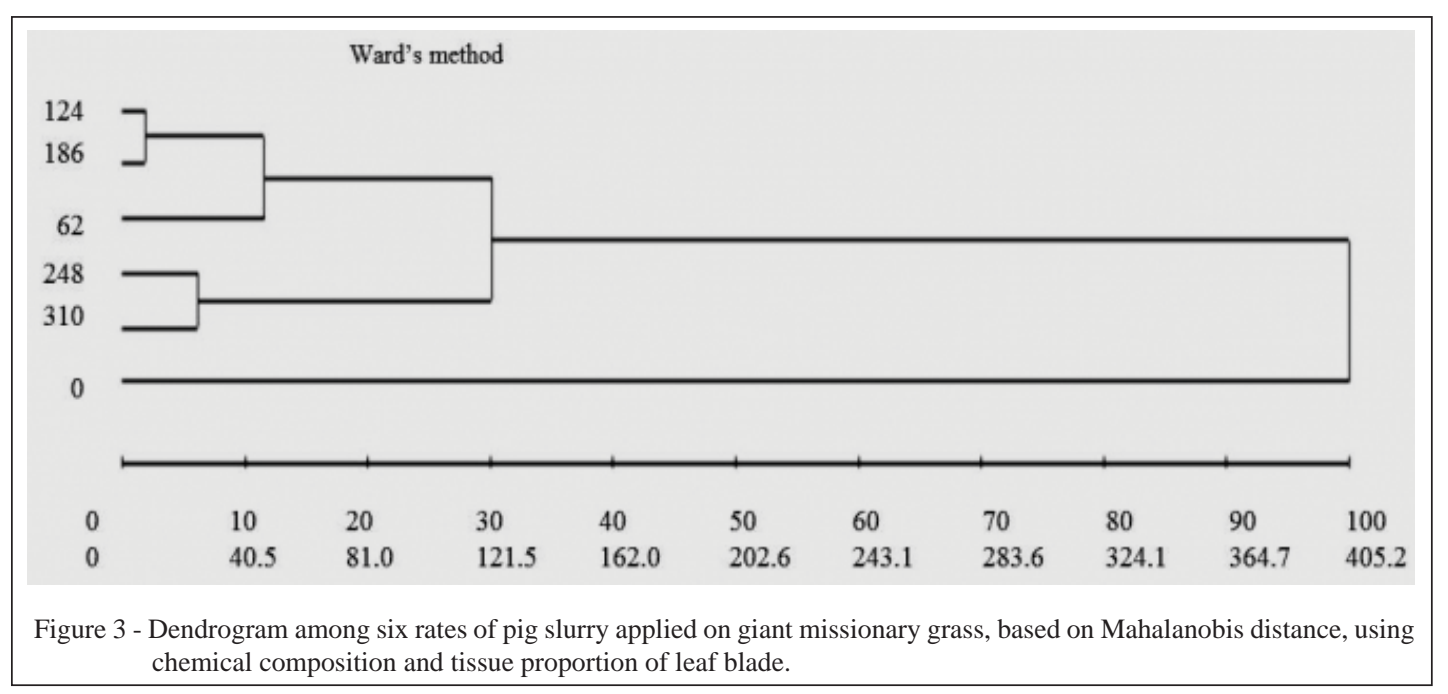

Ciência Rural, v.44, n.2, fev, 2014. 


\section{ACKNOWELEDGMENT}

To Conselho Nacional de Desenvolvimento Científico e Tecnológico (CNPq) (financial support), to EPAGRI-Chapecó and Dr. Mario Miranda (field experiment), and to SENAI-Chapecó (Image Pro Plus 5.0 software).

\section{REFERENCES}

ADELI, A. et al. Effects of swine lagoon effluent relative to commercial fertilizer applications on warm-season forage nutritive value. Agronomy Journal, v.97, p.408-417, 2005. Available from: <https://www.agronomy.org/publications/aj/abstracts/97/2/0408>. Accessed: Jan. 10, 2013. doi: 10.2134/agronj2005.0408.

AKIN, D.E. Histological and physical factors affecting digestibility of forages. Agronomy Journal, v.81, p.17-25, 1989. Available from: <https://www.crops.org/publications/aj/ abstracts/81/1/AJ0810010017>. Accessed: Jan. 10, 2013.

ALVES DE BRITO, C.J.F. et al. Anatomia quantitativa e degradação in vitro de tecidos em cultivares de capim-elefante (Pennisetum purpureum Schumach.). Revista Brasileira de Zootecnia, v.28, p.223-229, 1999. Available from: <http://dx.doi. org/10.1590/S1516-35982004000300001>. Accessed: Jan. 10, 2013. doi: 10.1590/S1516-35982004000300001.

BARNABÉ, M.C. et al. Produção e composição químicobromatológica da Brachiaria brizantha cv. 'Marandú' adubada com dejetos líquidos de suínos. Ciência Animal Brasileira, v.8, p.435-446, 2007. Available from: <http://www.revistas.ufg.br/ index.php/vet>. Accessed: Jan. 10, 2013.

BASSO, K.C. Morfogênese e anatomia foliar de Panicum maximum Jacq. cV ‘IPR-86 Milênio’ submetido a doses crescentes de nitrogênio. 2009. 71f. Tese (Doutorado em Zootecnia) Programa de Pós-graduação em Zootecnia, Universidade Estadual de Maringá, PR. Available from: <htpp://www.ppz.uem.br/ producao/getdoc.php?id=190>. Accessed: Jan. 10, 2013.

BELANGER, G.; McQUEEN, R.E. Leaf and stem nutritive value of timothy grown with varying $\mathrm{N}$ nutrition in spring and summer. Canadian Journal of Plant Science, v.79, p.223-229, 1999. Available from: <http://pubs.aic.ca/doi/pdf/10.4141/P98-077>. Accessed: Jan. 10, 2013. doi: 10.4141/P98-077.

BUXTON, D.R.; FALES, S.L. Plant environment and quality. In: FAHEY, G.C, Jr. (Ed.). Forage quality, evaluation, and utilization. Wisconsin: American Society of Agronomy, 1994. p.155-199.

CARVALHO, G.G.P.; PIRES, A.J.V. Organização dos tecidos de plantas forrageiras e suas implicações para os ruminantes. Archivos de Zootecnia, v.57, p.13-28, 2008. Available from: <http://www.uco.es/organiza/servicios/publica/az/php/img/web>. Accessed: 10 Jan. 2013.

CHESSON, A. et al. Degradation of isolated grass mesophyll, epidermis and fiber cell walls in the rumen and cellulolytic rumen bacteria in axenic culture. Journal of Applied Bacteriology, v.60, p.327-336, 1986.

CRUZ, C.D. Programa Genes - aplicativo computacional em genética e estatística. Viçosa: UFV, 1997. 442p.

DESCHAMPS, F.C.; TCACENCO, F.A. Parâmetros nutricionais de forrageiras nativas e exóticas no Vale do Itajaí, Santa Catarina. Pesquisa Agropecuária Brasileira, v.35, p.456465, 2000. Available from: <http://dx.doi.org/10.1590/S0100-
204X2000000200024>. Accessed: Jan. 10, 2013. doi: 10.1590/ S0100-204X2000000200024.

FERREIRA, D.F. Sisvar: a computer statistical analysis system. Ciência e Agrotecnologia, v.35, p.1039-1042, 2011.

FONTANELI, R.S. et al. Predição da composição química de bermudas (Cynodon spp.) pela espectroscopia de reflectância no infravermelho proximal. Revista Brasileira de Zootecnia, v.40, p.838-842, 2004. Available from: <http://dx.doi.org/10.1590/ S1516-35982004000400003>. Accessed: May 10, 2013. doi: 10.1590/S1516-35982004000400003.

LIMA, L.M. et al. Degradação ruminal dos tecidos vegetais e composição bromatológica de cultivares de Axonopus scoparius (Flüegge) Kuhlm. e Axonopus fissifolius (Raddi) Kuhlm. Ciencia Rural, v.31, p.509-515, 2001. Available from: <http://dx.doi. org/10.1590/S1516-3598201100110004>. Accessed: May 10, 2013. doi: 10.1590/S1516-3598201100110004.

MIRANDA, M. et al. Dry matter production and nitrogen use efficiency of giant missionary grass in response to pig slurry application. Revista Brasileira de Zootecnia, v.41, p.537543, 2012. Available from: <http://dx.doi.org/10.1590/S151635982012000300009>. Accessed: Jan. 10, 2013. doi: 10.1590/ S1516-35982012000300009.

PACIULLO, D.S.C. Características anatômicas relacionadas ao valor nutritivo de gramíneas forrageiras. Ciência Rural, v.32, p.357-364, 2002. Available from: <http://dx.doi.org/10.1590/ S0103-84782002000200029>. Accessed: Jan. 10, 2013. doi: 10.1590/S0103-84782002000200029.

QUEIROZ, D.S. et al. Avaliação da folha e do colmo de topo e base de perfilhos de três gramíneas forrageiras. 2. Anatomia. Revista Brasileira de Zootecnia, v.29, p.61-68, 2000. Available from: $<$ http://dx.doi.org/10.1590/S1516-35982000000100009>. Accessed: Jan. 10, 2013. doi: 10.1590/S1516-35982000000100009.

ROHWEDER, D.A. et al. Proposed hay grading standards based on laboratory analyses for evaluating quality. Journal of Animal Science, v.47, p.747-759, 1978. Available from: <http://www. journalofanimalscience.org/content/47/3/747.full.pdf+html>. Accessed: May 21, 2013.

SAHA, U.K et al. Common terms used in animal feeding and nutrition. Athens: University of Georgia Cooperative Extension Bulletin, 2010. Bulletin, 1367. Available from: <http://www.caes. uga.edu/publications>. Accessed: Jan. 21, 2013.

SCHEFFER-BASSO, S.M. et al. Resposta de pastagens perenes à adubação com chorume suíno: cultivar 'Tifton 85'. Revista Brasileira de Zootecnia, v.37, p.1940-1946, 2008. Available from: <http://dx.doi.org/10.1590/S1516-35982008001100006>. Accessed: Jan. 10, 2013. doi: 10.1590/S1516-35982008001100006.

SINGH, D. The relative importance of characters affecting genetic divergence. Indian Journal of Genetic and Plant Breeding, v.41, p.237-245, 1981.

VAN SOEST, P.J. et al. Methods for dietary fiber, neutral detergent fiber and non starch polysaccharides in relation to animal nutrition. Journal of Dairy Science, v.123, p.109-119, 1991. Available from: <http://www.journalofanimalscience.org/content/47/3/712>. Accessed: May 2, 2013.

VIELMO, H.B. et al. Effect of fertilization with fluid swine slurry on production and nutritive value of Tifton 85. Revista Brasileira de Zootecnia, v.40, p.60-68, 2011. Available from: <http://dx.doi. org/10.1590/S1516-35982011000100009>. Accessed: Jan. 10, 2013. doi: 10.1590/S1516-35982011000100009. 